\title{
PENERAPAN VECTOR AUTOREGRESSIVE INTEGRATED (VARI) PADA DATA JUMLAH PESERTA KB AKTIF
}

\author{
I. F. Yuliati ${ }^{1}$, A. N. Istinah ${ }^{2}$, dan P. R. Sihombing ${ }^{3}$ \\ 1Badan Kependudukan dan Keluarga Berencana Nasional \\ Jalan Permata No. 1, Jakarta Timur \\ 2Badan Pusat Statistik Kota Bandung, Jalan Jend. Gatot Soebroto No. 93 Bandung \\ 3Badan Pusat Statistik, Jalan Dr. Sutomo No 6-8, Jakarta Pusat \\ 1istiqomatul.fy@bkkbn.go.id , 2ahid@bps.go.id, 3robinson@bps.go.id
}

\begin{abstract}
The KKBPK program is one of the efforts made by the government through the National Population and Family Planning Agency (BKKBN) in overcoming population problems by the requirements, namely by using the amount in question through a fertility agreement. Garut and Bandung districts are priorities to control fertility which is monitored through active Family Planning development participants to make a significant contribution to the TFR and increase Contraceptive Use Rates in West Java Province. This study applies VARI in modelling active Family Planning participants in Garut and Bandung districts. The result of this research is number of active Family Planning participants in Garut and Bandung districts, influence each other lying down. The number of active family planning participants in Garut districts participation number of active Family Planning participants in the district. Garut in one previous period and by the number of active family planning participants in Bandung districts one last period. Thus, the number of active family planning participants in the district. Bandung, the number of active family planning participants in the area. Bandung in the previous period and by the number of active family planning participants in Garut districts one period before.
\end{abstract}

\section{Keywords : : Bandung, Family Planning, Garut, Vector Autoregressive Integrated}

\section{ABSTRAK}

Program KKBPK merupakan salah satu upaya yang telah dilakukan oleh pemerintah melalui Badan Kependudukan dan Keluarga Berencana Nasional (BKKBN) dalam menangani masalah kependudukan terutama dalam aspek kuantitas, yaitu dengan mengendalikan jumlah penduduk melalui penurunan fertilitas. Kab. Garut dan Kab. Bandung menjadi prioritas dalam rangka pengendalian fertilitas dipantau melalui perkembangan peserta KB aktif karena dianggap dapat memberikan sumbangan yang besar dalam menurunkan TFR dan meningkatkan Contraceptive Prevelance Rate (CPR) di Provinsi Jawa Barat. Penelitian ini menerapkan VARI dalam pemodelan peserta KB aktif pada Kab. Bandung dan Kab. Garut. Hasil penelitian yang didapat yaitu jumlah peserta KB aktif di Kab. Garut dan Kab. Bandung, saling mempengaruhi satu sama lain. Jumlah peserta KB aktif di Kab. Garut dipengaruhi oleh jumlah peserta KB aktif di Kab. Garut pada satu periode sebelumnya dan oleh jumlah peserta KB aktif di Kab. Bandung satu periode sebelumnya. Dengan 
demikian, Jumlah peserta KB aktif di Kab. Bandung dipengaruhi oleh jumlah peserta KB aktif di Kab. Bandung pada satu periode sebelumnya dan oleh jumlah peserta KB aktif di Kab. Garut satu periode sebelumnya.

Kata Kunci : Bandung, Keluarga Berencana, Garut, Vector Autoregressive Integrated

\section{PENDAHULUAN}

Pada dasarnya setiap nilai dari hasil pengamatan selalu dapat dikaitkan dengan waktu pengamatannya, hanya pada saat analisis, kaitan variabel waktu dengan pengamatan sering tidak dipersoalkan. Dalam hal kaitan variabel waktu dengan pengamatan diperhatikan, sehingga data dianggap sebagai fungsi atas waktu, maka data seperti ini dinamakan Data Deret Waktu (Mulyana, 2004). Wei (2006) menjelaskan bahwa berdasarkan jumlah variabel yang diamati, model deret waktu dapat dibagi menjadi dua, yaitu model deret waktu univariat dan model deret waktu multivariat.

Dalam melakukan analisis data deret waktu univariat, salah satu model yang digunakan adalah model Autoregressive (AR). Model AR adalah suatu model deret waktu yang menggambarkan pengamatan suatu variabel yang dipengaruhi variabel itu sendiri pada periode sebelumnya. Namun model AR hanya dapat diterapkan pada data yang stasioner. Pada kenyataannya, data deret waktu tidak selalu stasioner, ada kalanya mengandung pola musiman, siklis dan trend. Untuk data yang tidak stasioner atau mengikuti pola trend dapat dilakukan differencing, yaitu mengurangi nilai data pada suatu periode dengan nilai data periode sebelumnya. Untuk memodelkan data deret waktu univariat berupa data differencing digunakan model Autoregressive Integrated (ARI), sedangkan untuk data deret waktu multivariat digunakan model Vector Autoregressive Integrated (VARI).

Salah satu penerapan model VARI dapat diaplikasikan pada data perkembangan Program Kependudukan, Keluarga Berencana dan Pembangunan Keluarga (KKBPK) dari dua lokasi atau wilayah secara simultan. Program KKBPK merupakan salah satu upaya yang telah dilakukan oleh pemerintah melalui Badan Kependudukan dan Keluarga Berencana Nasional (BKKBN) dalam menangani masalah kependudukan terutama dalam aspek kuantitas, yaitu dengan mengendalikan jumlah penduduk melalui penurunan fertilitas. Berdasarkan Provinsi Jawa Barat Dalam Angka 2018 menyebutkan bahwa Kab. Garut memiliki kuantitas penduduk tertinggi kelima sebesar 2.588,84 juta jiwa dan Kab. Bandung memiliki kuantitas penduduk tertinggi kedua sebesar 3.534,11 juta jiwa. Disamping itu, berdasarkan hasil Survei Sosial Ekonomi Nasional (SUSENAS) tahun 2013 menunjukkan bahwa Total Fertility Rate (TFR) pada Kab. Garut sebesar 3,02 dan Kab. Bandung sebesar 2,42 lebih tinggi dibandingkan angka TFR Jawa Barat sebesar 2,37. Oleh karenanya, Kab. Garut dan Kab. Bandung menjadi prioritas dalam rangka pengendalian fertilitas dipantau melalui perkembangan peserta KB aktif karena dianggap dapat memberikan sumbangan yang besar dalam menurunkan TFR dan meningkatkan Contraceptive Prevelance Rate (CPR) di Provinsi Jawa Barat. 
Dalam pemilihan penggunaan alat kontrasepsi oleh para calon peserta KB untuk peningkatan kesertaan ber-KB, diduga setiap wilayah saling mempengaruhi satu sama lain, baik dikarenakan faktor kebijakan antar pemerintah daerah serta kedekatan antar wilayah yang membawa arus informasi tentang KB, sehingga dapat mempengaruhi pemakaian jenis alat kontrasepsi.

Berdasarkan keterangan di atas, maka diperlukan suatu analisis penerapan model VARI dalam pemodelan peserta KB aktif pada Kab. Bandung dan Kab. Garut. Hasil analisis ini diharapkan dapat dijadikan bahan penyusunan kebijakan yang perlu dipertimbangkan oleh Pemerintah dalam rangka mengendalikan jumlah penduduk melalui penurunan fertilitas.

\section{METODE PENELITIAN}

\subsection{Sumber Data dan Variabel Penelitian}

Data yang digunakan dalam analisis ini adalah data sekunder mengenai jumlah peserta KB aktif di Kab. Bandung dan Kab. Garut, Provinsi Jawa Barat, secara bulanan mulai dari bulan Januari 2008 sampai dengan Desember 2018. Data tersebut merupakan data yang dipublikasikan oleh Badan Kependudukan dan Keluarga Berencana Nasional (BKKBN) pada Program Aplikasi Statistik Rutin melalui aplikasi.bkkbn.go.id/sr.

Peserta KB aktif adalah Pasangan Usia Subur (PUS), dimana istrinya berumur antara 15 sampai dengan 49 tahun, yang saat ini menggunakan salah satu alat kontrasepsi tanpa diselingi kehamilan. Peserta KB aktif menurut jenis alat/cara kontrasepsi terdiri dari :

1. Peserta KB aktif kategori Metode Kontrasepsi Jangka Panjang (MKJP), yaitu Medis Operatif Wanita (MOW), Medis Operatif Pria (MOP), Implan dan Intra Uterine Device (IUD).

2. Peserta KB aktif kategori Non Metode Kontrasepsi Jangka Panjang (Non MKJP), yaitu Suntikan, Pil, dan Kondom.

\subsection{Model VAR}

Menurut Wei (2006) deret waktu merupakan suatu pengamatan yang tersusun berdasarkan urutan waktu kejadian dengan interval waktu yang sama. Metode deret waktu merupakan salah satu analisis yang mempelajari data deret waktu, baik dari segi teori maupun membuat peramalan. Wei (2006) menjelaskan bahwa berdasarkan jumlah variabel yang diamati, model deret waktu dapat dibagi menjadi dua, yaitu model univariat dan multivariat. Model deret waktu univariat adalah model deret waktu yang melibatkan satu variabel runtun waktu. Sedangkan, model deret waktu multivariat adalah model deret waktu yang melibatkan lebih dari satu variabel runtun waktu. Deret waktu multivariat merupakan deret waktu yang terdiri dari beberapa variabel yang pada umumnya digunakan untuk memodelkan dan menjelaskan interaksi serta pergerakan diantara sejumlah variabel deret waktu. 
Tahapan dalam pemodelan Vector Autoregressive Integrated (VARI) dalam analisis ini adalah sebagai berikut :

\subsubsection{Uji Korelasi}

Untuk menerapkan model VAR terlebih dahulu akan dilihat korelasi variable-variabel yang akan dilibatkan dalam analisis dengan menggunakan rumus sebagai berikut:

$$
r=\frac{n \cdot \sum X Y-\sum X \cdot \sum Y}{\sqrt{n \cdot \sum X^{2}-\left(\sum X\right)^{2}} \cdot \sqrt{n \cdot \sum Y^{2}-\left(\sum Y\right)^{2}}}
$$

\subsubsection{Stasioneritas Data}

Kestasioneran data merupakan kondisi yang diperlukan dalam analisis regresi deret waktu karena dapat memperkecil kekeliruan model, sehingga jika data tidak stasioner, maka harus dilakukan transformasi stasioneritas melalui proses diferensi, jika trendnya linier, sedangkan jika tidak linier, maka transformasinya harus dilakukan dulu transformasi linieritas trend melalui proses logaritma natural jika trendnya eksponensial, dan proses pembobotan (penghalusan eksponensial sederhana) jika bentuknya yang lain, yang selanjutnya proses diferensi pada data hasil proses linieritas.

Kestasioneran dalam rata-rata dapat diidentifikasi secara visual, tahap pertama dapat dilakukan pada peta data atas waktu menggunakan plot time series, karena biasanya "mudah", dan jika belum mendapatkan kejelasan, maka tahap berikutnya ditelaah pada gambar Autocorrelation Function (ACF) dengan Partial Autocorrelation Function (PACF) yang akan dijelaskan selanjutnya. Jika telaahan kestasioneran dalam rata-rata secara "visual" kurang meyakinkan, maka pengujian hipotesis statistis untuk kestasioneran data perlu dilakukan menggunakan Augmented Dickey-Fuller Test.

$\begin{array}{lll}\text { Hipotesis } & \boldsymbol{H}_{\mathbf{0}}: \boldsymbol{\gamma}=\mathbf{0} & \text { (data bersifat tidak stasioner) } \\ & \boldsymbol{H}_{\mathbf{0}}: \boldsymbol{\gamma}<\mathbf{0} & \text { (data bersifat stasioner) }\end{array}$

Statistik uji : : Augmented Dickey-Fuller Test.

$$
t_{\text {hit }}=\frac{\widehat{\gamma}}{\operatorname{se}(\widehat{\gamma})}
$$

dengan :

$\widehat{\gamma} \quad=$ nilai dugaan $\gamma$

$\boldsymbol{s e}(\widehat{\gamma})=\operatorname{simpangan}$ baku dari $\boldsymbol{\gamma}$

Kriteria uji: Tolak $\mathrm{HO}$ jika $p$-value $<\alpha$, terima dalam hal lainnya.

Kestasioneran varians dalam model deret waktu dapat dilakukan secara visual dengan menggunakan plot time series dengan melihat pola data apakah melebar atau menyempit, sedangkan pengujian stasioner varians dapat dijelaskan dalam bentuk plot Box-Cox. Menurut Rosmanicke (2009) dalam Mulyaningsih (2013) jika nilai batas bawah dan batas atas lambda 
( $\lambda$ ) plot Box-Cox dari data deret waktu melalui nilai satu, maka dapat dikatakan bahwa data deret waktu tersebut sudah stasionerdalam varians. Jika varians tidak stasioner dapat diatasi dengan menggunakan transformasi Box-Cox pada data deret waktu tersebut.

\subsection{Autocorrelation Function (ACF) dan Partial Autocorrelation Function (PACF)}

Visualisasi ACF dan PACF menggunakan korelogram (correlogram) yang dapat digunakan untuk menelaah signifikansi autokorelasi dan kestasioneran data. Telaahan pada gambar ACF untuk melihat kestasioneran data adalah jika data tidak stasioner maka gambarnya akan membangun pola :Menurun, jika data tidak stasioner dalam rata-rata hitung (trend naik atau turun), Alternating, jika data tidak stasioner dalam varians. Gelombang, jika data tidak stasioner dalam rata-rata hitung dan varians.

Konsepsi autokorelasi setara (identik) dengan korelasi Pearson untuk data bivariat. Deskripsinya sebagai berikut, jika dimiliki sampel data deret waktu $x_{1}, x_{2}, \ldots, x_{n}$, dan dapat dibangun pasangan nilai $\left(\mathrm{x}_{1}, \mathrm{xk}_{+1}\right),\left(\mathrm{x}_{2}, \mathrm{x}_{\mathrm{k}+2}\right), \ldots,\left(\mathrm{x}_{\mathrm{k}}, \mathrm{x}_{\mathrm{n}}\right)$, autokorelasilasi lag-k, dari sampel data deret waktu adalah :

$$
r_{k}=\frac{\sum_{t=1}^{n-k}\left(x_{t}-\bar{x}\right)\left(x_{t+k}-\bar{x}\right)}{\sqrt{\sum_{t=1}^{n}\left(x_{t}-\bar{x}\right)^{2}}}
$$

Karena rk merupakan fungsi atas $\mathrm{k}$, maka hubungan autokorelasi dengan lagnya dinamakan Fungsi Autokorelasi (autocorrelation function, ACF), dan dinotasikan oleh :

$$
\rho(k)=\frac{\sum_{t=1}^{n-k}\left(x_{t}-\bar{x}\right)\left(x_{t+k}-\bar{x}\right)}{\sqrt{\sum_{t=1}^{n}\left(x_{t}-\bar{x}\right)^{2}}}
$$

Konsepsi lain pada autokorelasi adalah autokorelasi parsial (partial autocorrelation), yaitu korelasi antara $X_{t}$ dengan $X_{t+k}$, dengan mengabaikan ketidak-bebasan $X_{t+1}, X_{t+2}, \ldots$, $X_{t+k-1}$, sehingga $X t$ dianggap sebagai konstanta, $X_{t}=X_{t}, t=t+1, t+2, \ldots, t+k-1$. Autokorelasi parsial $\mathrm{Xt}$ dengan $\mathrm{X}_{\mathrm{t}+\mathrm{k}}$ didefinisikan sebagai korelasi bersyarat :

$$
\rho k k=k o r .\left(X_{t}, X_{t+k} \mid X_{t+1}=x_{t+1} \quad, X_{t+2}=X_{t+2}, \ldots, X_{t+k-1}=x_{t+k-1}\right)
$$

Seperti halnya autokorelasi yang merupakan fungsi atas lagnya, yang hubungannya dinamakan fungsi autokorelasi (ACF), autokorelasi parsial juga merupakan fungsi atas lagnya, dan hubungannya dinamakan Fungsi Autokorelasi Parsial (partial autocorrelation function, PACF). Gambar dari ACF dan PACF (korelogram) untuk menelaah signifikansi autokorelasi adalah jika gambar ACF membangun sebuah histogram yang menurun (pola eksponensial), maka autokorelasi signifikans atau data berautokorelasi, dan jika diikuti oleh gambar PACF 
yang histogramnya langsung terpotong pada lag-2, maka data tidak stasioner, dan dapat distasionerkan melalui proses diferensi. Jika hasil telaahan secara "visual" tidak cukup menyakinkan, maka dapat dilakukan pengujian hipotesis statistis untuk keberartian autokorelasi.

\subsection{Model Autoregresive (AR)}

Model Autoregressive (AR) adalah suatu model yang menggambarkan bahwa nilai dari proses saat ini $\left(Z_{t}\right)$ masih berhubungan dengan nilai atau data masa lalu. Misalkan nilai $Z$ pada waktu $t$ dinyatakan sebagai kombinasi linear dari nilai-nilai $Z$ pada waktu sebelumnya ditambah error seperti pada persamaan:

$$
Z(t)=\phi_{1} Z(t-1)+\phi_{2} Z(t-2)+\cdots+\phi_{p} Z(t-p)+\varepsilon(t)
$$

ekuivalen dengan

$$
\left(1-\phi_{1} B-\phi_{2} B^{2}-\cdots-\phi_{p} B^{p}\right) Z_{t}=\varepsilon(t)
$$

atau

dimana

$$
\phi_{p}(B) Z(t)=\varepsilon(t)
$$

$$
\phi_{p}(B)=1-\sum_{j=1}^{p} \phi_{j} B^{j}, \text { dan } 1+\sum_{j=1}^{p}\left|\phi_{j}\right|<\infty
$$

Untuk kestasioneran, akar dari $\mathbf{1}-\boldsymbol{\phi}_{\mathbf{1}} \boldsymbol{B}=\mathbf{0}$ harus terletak diluar lingkaran satuan, artinya bahwa apabila $\left|\boldsymbol{\phi}_{j}\right|<\mathbf{1}$ maka proses sudah dikatakan stasioner.

\subsection{Differencing}

Salah satu cara untuk menstasionerkan data adalah dengan differencing. Metode ini dilakukan dengan cara mengurangi nilai data pada suatu periode dengan nilai data periode sebelumnya. Differencing pertama (first differencing) dari suatu data deret waktu $\boldsymbol{Z}_{\boldsymbol{t}}$ dapat didefinisikan dengan persamaan :

$$
Z^{\prime}(t)=(1-B) Z(t)=Z(t)-Z(t-1)
$$

\subsection{Model Autoregresive Integrated (ARI)}

Jika data deret waktu mengandung trend, maka salah satu cara menstasionerkannya adalah dengan differencing. Data yang merupakan model AR orde 1 dan mengalami proses differencing pertama untuk menghasilkan data yang stasioner, akan menjadi model $\operatorname{ARI}(1,1)$, yaitu:

$$
\begin{aligned}
& \dot{Y}(t)=\phi_{1} \dot{Y}(t-\mathbf{1})+\varepsilon(t) \\
& \text { dengan, } \varepsilon(t) \sim N\left(\mathbf{0}, \sigma^{2}\right) \text { dan } \dot{Y}(t)=\dot{Z}(t)-\dot{Z}(t-1) \text {, sehingga persamaan (11) dapat }
\end{aligned}
$$
ditulis sebagai berikut:

$$
\dot{Z}(t)-\dot{Z}(t-1)=\phi_{1}(\dot{Z}(t-1)-\dot{Z}(t-2))+\varepsilon(t), \quad \varepsilon(t) \sim N\left(\mathbf{0}, \sigma^{2}\right)
$$




\subsection{Model Vector Autoregresive VAR}

Untuk suatu sistem sederhana dengan dua peubah (bivariate model) dengan kelambanan satu, model simultan yang dibentuk adalah sebagai berikut:

$$
\begin{aligned}
& Z_{1}(t)=\phi_{11} Z_{1}(t-1)+\phi_{12} Z_{2}(t-1)+\varepsilon_{1}(t) \\
& Z_{2}(t)=\phi_{21} Z_{1}(t-1)+\phi_{22} Z_{2}(t-1)+\varepsilon_{2}(t)
\end{aligned}
$$

Dengan asumsi: (a) $\boldsymbol{Z}_{1}(t)$ dan $\boldsymbol{Z}_{2}(t)$ stasioner, (b) $\boldsymbol{\varepsilon}_{1}(t)$ dan $\boldsymbol{\varepsilon}_{2}(t)$ adalah error dengan simpangan baku $\sigma_{Z_{1}}^{2}$ dan $\sigma_{Z_{2}}^{2}$, (c) $\varepsilon_{1}(t)$ dan $\varepsilon_{2}(t)$ tidak berkorelasi.

Kedua persamaan diatas memiliki struktur timbal balik (feedback) karena $\boldsymbol{Z}_{\mathbf{1}}(\boldsymbol{t})$ dan $Z_{2}(t)$ saling memberikan pengaruh satu sama lain. Persamaan ini merupakan persamaan VAR struktural. Dengan menggunakan aljabar matriks, kedua sistem diatas dapat dituliskan sebagai berikut:

$$
\left[\begin{array}{l}
Z_{1}(t) \\
Z_{2}(t)
\end{array}\right]=\left[\begin{array}{ll}
\phi_{11} & \phi_{12} \\
\phi_{21} & \phi_{22}
\end{array}\right]\left[\begin{array}{l}
Z_{1}(t-1) \\
Z_{2}(t-1)
\end{array}\right]+\left[\begin{array}{l}
\varepsilon_{1}(t) \\
\varepsilon_{2}(t)
\end{array}\right]
$$

Karena peubah-peubah endogen dalam persamaan VAR hanya terdiri dari beda lag semua peubah endogen, kesimultanan bukan suatu persoalan dan pendugaan Ordinary Least Square (OLS) atau metode kuadrat terkecil menghasilkan dugaan yang konsisten.

\subsection{Model Vector Autoregresive Integrated (VARI)}

Model VARI merupakan pengembangan dari model Autoregressive Integrated (ARI) yang dipengaruhi oleh variabel itu sendiri dan variabel lain pada periode sebelumnya dengan data tidak stasioner. Jika data mengalami proses differencing pertama untuk menghasilkan data yang stasioner, maka bentuk model VAR(1)menjadi model VARI $(1,1)$ dengan persamaan sebagai berikut:

$\dot{Z}_{1}(t)-\dot{Z}_{1}(t-1)=\phi_{11}\left(\dot{Z}_{1}(t-1)-\dot{Z}_{1}(t-2)\right)+\cdots+\phi_{1 N}\left(\dot{Z}_{N}(t-1)-\dot{Z}_{N}(t-2)\right)+\varepsilon_{1}(t)$
$\dot{Z}_{2}(t)-\dot{Z}_{2}(t-1)=\phi_{21}\left(\dot{Z}_{1}(t-1)-\dot{Z}_{1}(t-2)\right)+\cdots+\phi_{2 N}\left(\dot{Z}_{N}(t-1)-\dot{Z}_{N}(t-2)\right)+\varepsilon_{2}(t)$
$\vdots$

$\dot{Z}_{N}(t)-\dot{Z}_{N}(t-1)=\phi_{N 1}\left(\dot{Z}_{1}(t-1)-\dot{Z}_{1}(t-2)\right)+\cdots+\phi_{N N}\left(\dot{Z}_{N}(t-1)-\dot{Z}_{N}(t-2)\right)+\varepsilon_{N}(t)$

Sehingga dalam bentuk matriks menjadi :

$\left[\begin{array}{c}\dot{Z}_{1}(t)-\dot{Z}_{1}(t-1) \\ \dot{Z}_{2}(t)-\dot{Z}_{2}(t-1 \\ \vdots \\ \dot{Z}_{N}(t)-\dot{Z}_{N}(t-1)\end{array}\right]=\left[\begin{array}{cccc}\phi_{11} & \phi_{12} & \cdots & \phi_{1 N} \\ \phi_{21} & \phi_{22} & \cdots & \phi_{2 N} \\ \vdots & \vdots & \ddots & \vdots \\ \phi_{N 1} & \phi_{N 2} & \cdots & \phi_{N N}\end{array}\right]\left[\begin{array}{c}\dot{Z}_{1}(t-1)-\dot{Z}_{1}(t-2) \\ \dot{Z}_{2}(t-1)-\dot{Z}_{2}(t-2) \\ \vdots \\ \dot{Z}_{N}(t-1)-\dot{Z}_{N}(t-2)\end{array}\right]+\left[\begin{array}{c}\varepsilon_{1}(t) \\ \varepsilon_{2}(t) \\ \vdots \\ \varepsilon_{N}(t)\end{array}\right]$ 
Ekuivalen dengan

$\left[\begin{array}{c}\dot{Z}_{1}(t) \\ \dot{Z}_{2}(t) \\ \vdots \\ \dot{Z}_{N}(t)\end{array}\right]-\left[\begin{array}{c}\dot{Z}_{1}(t-1) \\ \dot{Z}_{2}(t-1) \\ \vdots \\ \dot{Z}_{N}(t-1)\end{array}\right]=\left[\begin{array}{cccc}\phi_{11} & \phi_{12} & \cdots & \phi_{1 N} \\ \phi_{21} & \phi_{22} & \cdots & \phi_{2 N} \\ \vdots & \vdots & \ddots & \vdots \\ \phi_{N 1} & \phi_{N 2} & \cdots & \phi_{N N}\end{array}\right]\left(\left[\begin{array}{c}\dot{Z}_{1}(t-1) \\ \dot{Z}_{2}(t-1) \\ \vdots \\ \dot{Z}_{N}(t-1)\end{array}\right]-\left[\begin{array}{c}\dot{Z}_{2}(t-2) \\ \dot{Z}_{2}(t-2) \\ \vdots \\ \dot{Z}_{N}(t-2)\end{array}\right]\right)+\left[\begin{array}{c}\varepsilon_{1}(t) \\ \varepsilon_{2}(t) \\ \vdots \\ \varepsilon_{N}(t)\end{array}\right]$

atau dapat ditulis

$\dot{Z}(t)-\dot{Z}(t-1)=\Phi\left(\dot{Z}_{1}(t-1)-\dot{Z}_{1}(t-2)\right)+\vec{\varepsilon}(t)$

Diasumsikan bahwa galat berdistibusi normal, $\vec{\varepsilon}(t) \sim N\left(\mathbf{0}, \sigma^{2}\right)$ dan $\dot{Y}(t)=\dot{Z}(t)-\dot{Z}(t-$ 1). Sebelum pemodelan VARI dilakukan, perlu menentukan panjang lag dalam model VARI menunjukkan banyaknya parameter yang akan diduga. Jika panjang lag dilambangkan dengan $\boldsymbol{p}$, maka setiap $\boldsymbol{n}$ persamaan berisi $\boldsymbol{n} \boldsymbol{p}$ koefisien ditambah intersep. Semakin panjang lag yang didapat maka semakin banyak pula data yang harus disediakan agar sebuah model dapat menangkap sebuah fenomena dengan baik. Penentuan panjang lag harus dilakukan secara hati-hati agar seluruh dinamika dalam sistem dapat dimodelkan dengan tepat.

Indikator yang umumnya digunakan adalah Akaike Information Criterion (AIC) dan Schwarz Information Criterion (SIC). Model dengan nilai AIC dan SIC terendah akan dipilih sebagai panjang kelambanan optimal dari model VAR (Enders 1995). Hal ini dikarenakan, semakin kecilnya nilai AIC dan SIC, maka nilai harapan yang dihasilkan oleh sebuah model akan semakin mendekati kenyataan.

Perhitungan nilai AIC dan SIC meggunakan rumus sebagai berikut :

$A I C=T \ln ($ sum of squared residuals $)+2 n$

$S I C=T \ln ($ sum of squared residuals $)+n \ln (T)$

dengan :

$\mathrm{t}=$ banyaknya observasi

$\mathrm{n}=$ banyaknya parameter yang diestimasi $(\mathrm{p}+\mathrm{q}+$ konstanta yang mungkin terbentuk $)$

Setelah dilakukan identifikasi model dan diketahui orde dari model VARI, maka langkah selanjutnya adalah melakukan estimasi terhadap parameter model VARI. Estimasi yang efisien yaitu estimasi yang meminimumkan kuadrat selisih antara nilai estimasi dengan nilai parameter.

Selanjutnya, setelah estimasi parameter model VARI diperoleh maka dilakukan uji-t untuk mengetahui apakah parameter secara parsial sudah signifikan dalam model dan uji-F untuk mengetahui apakah parameter secara serentak sudah signifikan dalam model. 


\subsection{Diagnostik Model}

Uji Multivariate White Noise Residual

\section{Hipotesis}

$\boldsymbol{H}_{\mathbf{0}}: \boldsymbol{E}\left(\varepsilon_{t} \varepsilon_{t-\boldsymbol{i}}\right)=\mathbf{0}$ atau model sudah memenuhi multivariate white noise

$\boldsymbol{H}_{1}$ : Minimal ada satu $\left(\varepsilon_{t} \varepsilon_{t-i}\right) \neq \mathbf{0}$, atau model belum memenuhi multivariate white noise, dengan $\mathrm{I}=3,4, \ldots, 10$

Statistik Uji : Portmanteau Test

$Q=T(T+2) \sum_{h=1}^{h} \frac{\hat{r}_{h}^{2}}{T-h}$

dengan:

$\mathrm{T}$ : banyaknya sisaan

$\hat{r}_{h}$ : autokorelasi antar sisaan

$\mathrm{h}: \operatorname{lag}$

Kriteria uji

Statistik $Q$ untuk model VAR mengikuti sebaran Chi-Square dengan derajat bebas $\boldsymbol{n}^{2}(\boldsymbol{h}-\boldsymbol{p})$, dimana $n$ = banyaknya peubah dalam VAR, $p=$ orde VAR, $h=$ lag (Eviews, 2002). Jika nilai $\boldsymbol{p}$-value $>\boldsymbol{\alpha}$ maka terima $\boldsymbol{H}_{\mathbf{0}}$ atau model memenuhi syarat multivariate white noise.

\subsection{Uji Residual Berdistribusi Multivariate Normal} Hipotesis

$\boldsymbol{H}_{\mathbf{0}}$ : residual berdistribusi normal multivariate

$\boldsymbol{H}_{\mathbf{1}}$ : residual tidak berdistribusi normal multivariate

Statistik Uji : Multivariat Jarque-Berra (MJB) Test

$J B=n \frac{\left(\sqrt{b_{1}}\right)^{2}}{6}+\frac{\left(b_{2}-3\right)^{2}}{24}$

(23) dengan:

b1 : kemencengan

b2 : kurtosis

Kriteria uji

Kondisi hipotesis nol Jarque Berra (JB) memiliki derajat bebas 2. Jika nilai $\boldsymbol{p}$-value $>\boldsymbol{\alpha}$ maka terima $\boldsymbol{H}_{\mathbf{0}}$ atau model memenuhi syarat multivariate normal. 


\subsection{Uji Kehomogenan Ragam Residual}

Heteroscedasticity adalah suatu asumsi dasar yakni kondisi dimana varians dari setiap error term adalah konstan atau berbeda-beda. Jika kondisi ini tidak tercapai maka tiap observasi akan memiliki derajat reliabilitas yang berbeda-beda. Akibatnya adalah proses estimasi menjadi tidak efisien, sedangkan jika tetap dilakukan maka hasilnya konsisten dan tidak bias. Uji Homoskedastisitas residual menggunakan uji ARCH-LM adalah sebagai berikut: Hipotesis

$$
\begin{aligned}
& H_{0}: \text { Kuadrat residual tidak menunjukkan heteroskedatisitas } \\
& H_{1}: \text { Kuadrat residual menunjukkan heteroskedatisitas }
\end{aligned}
$$

Statistik Uji : ARCH-LM Test

Uji ARCH-LM dilakukan dengan cara meregresikan kuadrat residual $\left(\varepsilon_{t}^{2}\right)$ model sehingga diperoleh taksiran sebagai berikut :

$\varepsilon_{t}^{2}=\alpha_{0}+\alpha_{1} \varepsilon_{t-1}^{2}+\cdots+\alpha_{q} \varepsilon_{t-q}^{2}+v_{t}$

$L M=T \times R^{2}$

dengan:

$T$ = banyaknya pengamatan

$R^{2}=$ koefisien determinasi dari model regresi $\varepsilon_{t}^{2}$ dan $q$ = banyaknya pengamatan yang mempengaruhi.

Kriteria uji: Jika $L M$ lebih besar dari $\chi_{q}^{2}$, mengindikasikan adanya pengaruh ARCH. (Enders, 1995). Jika nilai $p$-value $>\alpha$ maka terima $H_{0}$ atau model memenuhi syarat homogenitas residual.

\section{HASIL DAN PEMBAHASAN}

\subsection{Analisis Deskriptif}

Sebelum masuk dalam tahap analisis, eksplorasi data secara univariat dilakukan untuk melihat gambaran dari data yang digunakan dalam analisis ini. Analisis awal menunjukkan bahwa rata-rata jumlah peserta KB aktif pada Kab. Garut sebesar 354.213, dimana rentang nilainya antara 310.195 - 398.958, serta simpangan baku sebesar 21.158,59. Rata-rata jumlah peserta KB aktif pada Kab. Bandung sebesar 530.795, dimana rentang nilainya antara 427.969 - 604.382, serta simpangan baku sebesar 45.298,49. Nilai korelasi antar variabel sebesar 0,9341966 sehingga dapat disimpulkan bahwa antar lokasi saling berkorelasi. Oleh karena itu, penerapan model VAR dapat dilanjutkan. 


\subsection{Uji Stasioneritas Data}

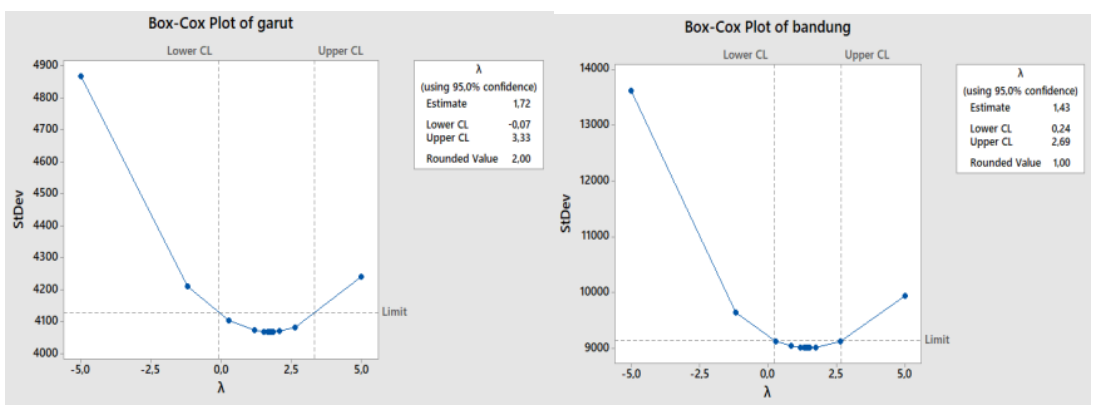

Gambar 1 : Plot Box-Cox Jumlah Peserta KB Aktif di Kab. Garut dan Kab. Bandung

Berdasarkan plot di atas menunjukkan bahwa nilai batas atas dan batas bawah lambda ( $\lambda$ ) pada data jumlah peserta KB aktif pada Kab. Garut dan Kab. Bandung melalui nilai satu. Hal ini dapat dianggap bahwa varians data sudah stasioner, sehingga dalam analisis ini tidak dilakukan transformasi karena belum ada jaminan bahwa model yang didapatkan dari hasil transformasi akan lebih baik daripada model tanpa transformasi.
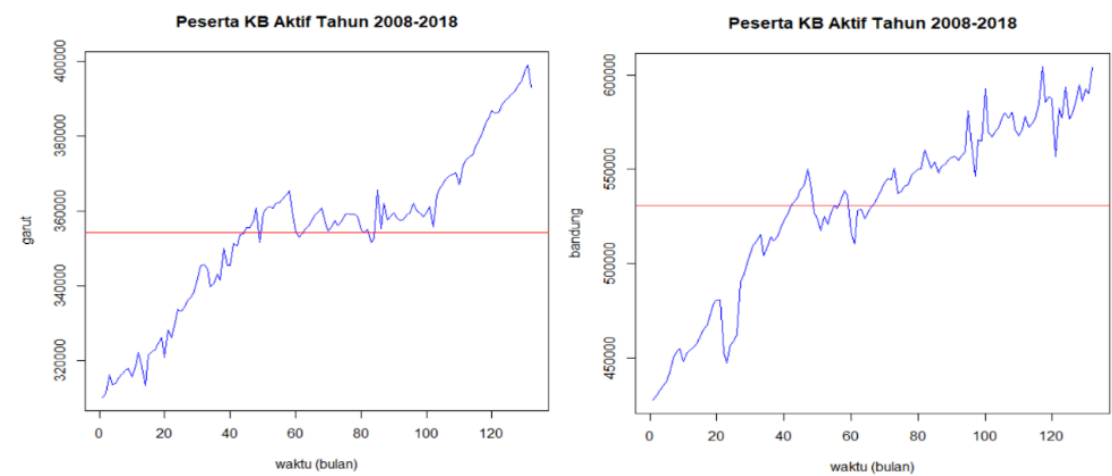

Gambar 2 : Plot Jumlah Peserta KB Aktif di Kab. Garut dan Kab. Bandung

Berdasarkan plot di atas menunjukkan pola trend linier sehingga dapat diduga data jumlah peserta KB aktif di Kab. Garut dan Kab. Bandung tidak stasioner. Namun, untuk lebih meyakinkan dapat mengunakan Augmented Dickey-Fuller (ADF) Test. ADF Test di bawah ini menunjukkan bahwa masing masing nilai p-value untuk Kab. Garut dan Kab. Bandung adalah 0.8062 dan 0.2122 . Karena nilai $p$-value lebih besar dari $\alpha=5 \%$, maka dapat disimpulkan bahwa data tersebut tidak stasioner sehingga data perlu dilakukan differencing. 

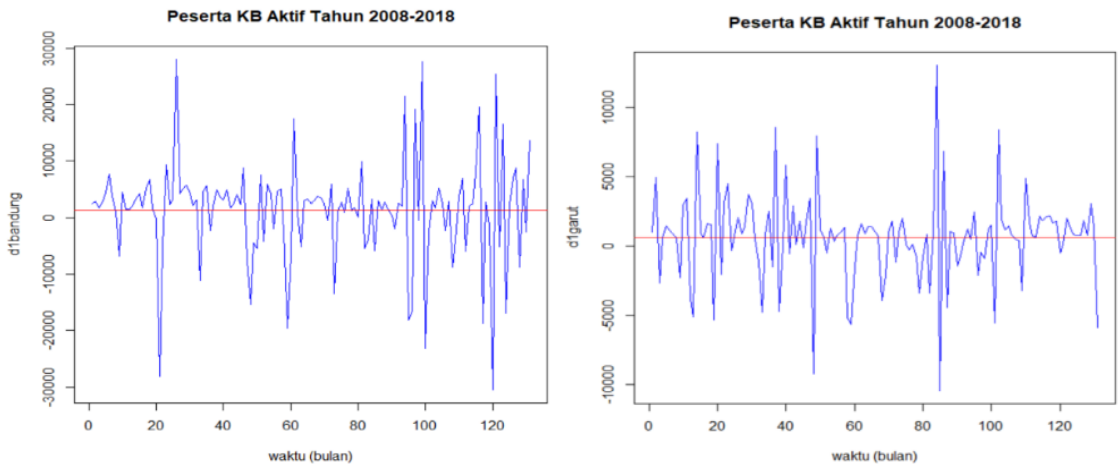

Gambar 3 : Plot Data Hasil First Differencing $(\mathrm{d}=1)$

Setelah data dilakukan proses differencing satu kali, plot menunjukkan pola data dengan trend mendatar dan pola "terompet disisi kiri dan kanan". Hal ini berarti differencing orde-1 menjadi stasioner kuat dalam rata-rata hitung. Selain itu, hasil ADF Test menunjukan bahwa nilai $p$-value masing masing untuk Kab. Garut dan Kab. Bandung adalah 0.01 lebih besar dari $\alpha=5 \%$, maka dapat disimpulkan bahwa data tersebut stasioner pada proses first differencing.
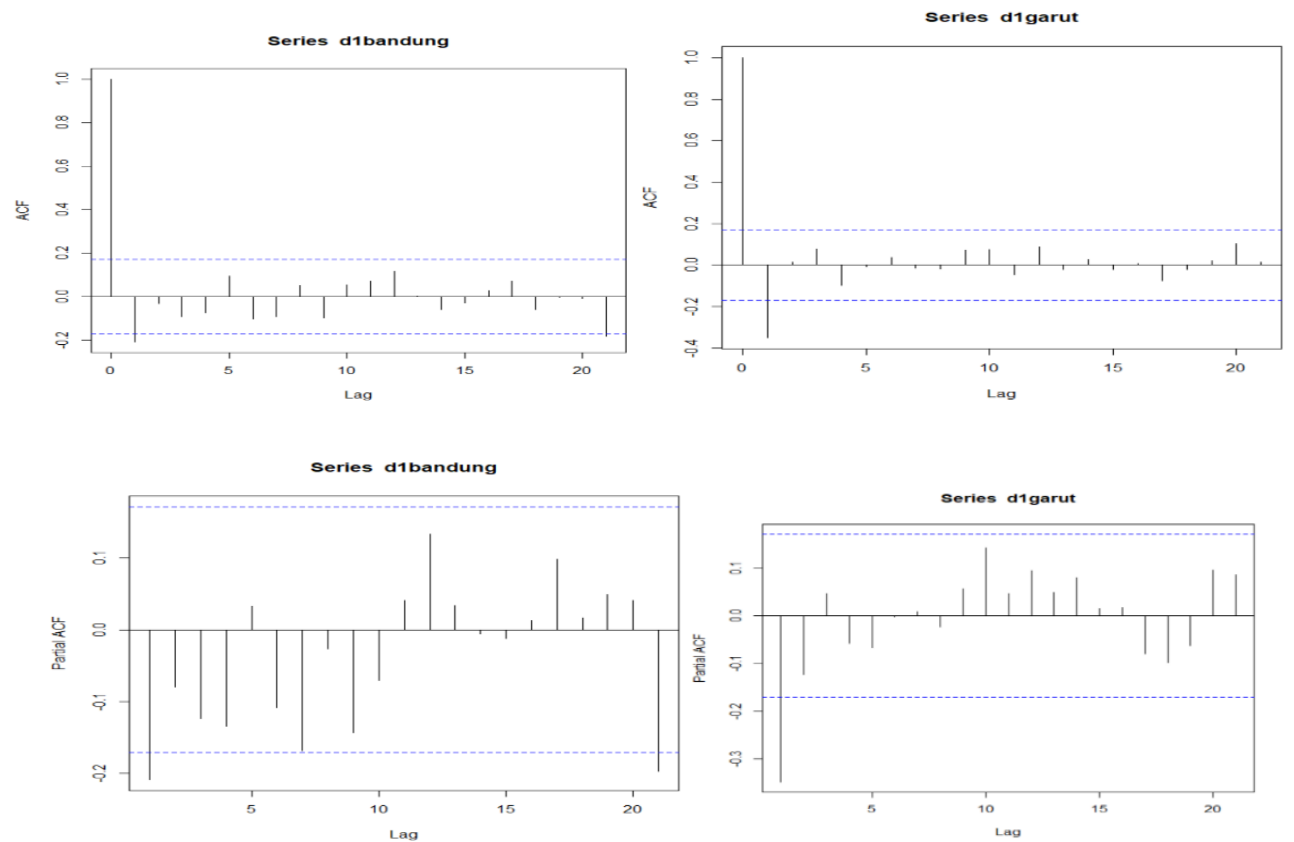

Gambar 4 : Kolerogram (ACF dan PACF) Hasil First Differencing $(\mathrm{d}=1)$

Gambar 4 menunjukkan bahwa pada grafik ACF Kab. Garut dan Kab. Bandung dari lag ke-1 hingga seterusnya membentuk pola sinus damped dan pada grafik PACF Kab. Garut dan Kab. Bandung terlihat pada lag ke-1 keluar dari garis sehingga dapat dikatakan bahwa data 
signifikan pada lag ke-1. Hal ini menunjukkan bahwa data jumlah peserta KB aktif pada Kab. Garut dan Kab. Bandung first diffierencing dapat dimodelkan dengan menggunakan VARI $(1,1)$.

\subsection{Pemilihan Panjang Lag (Orde) Optimal}

Pada keterangan sebelumnya menunjukkan bahwa data first diffierencing signifikan pada lag ke-1 berdasarkan grafik PACF. Namun, untuk lebih meyakinkan dalam pemilihan lag optimal bisa menggunakan nilai AIC, HQ, SC dan FPE.

Pada output di bawah ini diperoleh nilai AIC, HQ, SC dan FPE terkecil untuk data first diffierencing ada pada lag ke-1, yang mengindikasikan bahwa model yang terbaik adalah VARI orde ke-1 atau $\operatorname{VARI}(1,1)$. Penggunaan orde 1 ini juga dapat diartikan bahwa kedua variabel pengamatan saling mempengaruhi satu sama lain tidak hanya pada periode yang sama, tetapi juga pada satu periode sebelumnya.

Tabel 1 : Hasil Estimasi Model VARI(1,1)

\begin{tabular}{|c|c|c|c|c|c|}
\hline Persamaan & Variabel & Koef. & $\begin{array}{c}\text { F- } \\
\text { value }\end{array}$ & $\begin{array}{l}\text { degress } \\
\text { of freedom } \\
\text { (df) }\end{array}$ & $\begin{array}{l}\text { P- } \\
\text { value } \\
\text { (Simultan) }\end{array}$ \\
\hline \multirow{3}{*}{ Garut } & constanta & 849.038 & \multirow{3}{*}{2,992} & \multirow{3}{*}{2,127} & \multirow{3}{*}{0.000} \\
\hline & Garutt-1 & -0.380 & & & \\
\hline & Bandungt- & 0.032 & & & \\
\hline \multirow{3}{*}{ Bandung } & constanta & 1646.217 & \multirow{3}{*}{2,992} & \multirow{3}{*}{2,127} & \multirow{3}{*}{0.054} \\
\hline & Garutt-1 & -0.079 & & & \\
\hline & Bandungt- & -0.206 & & & \\
\hline
\end{tabular}

Persamaan VARI $(1,1)$ juga dapat kita tuliskan dengan :

Garut $_{t}=849.038-0.380$ Garut $_{t-1}+0.032$ Bandung $_{t-1}$

Bandung $_{t}=1646.217-0.079$ Bandung $_{t-1}-0.206$ Garut $_{t-1}$

dengan asumsi $\varepsilon_{1}(t), \varepsilon_{2}(t) \sim N\left(\mu, \sigma^{2}\right)$

Dengan menggunakan taraf signifikansi $10 \%$, diperoleh bahwa kedua persamaan signifikan secara simultan (uji-F). Dua persamaan diatas menunjukkan bahwa variabel yang diamati, yaitu jumlah peserta KB aktif di Kab. Garut dan Kab. Bandung, saling mempengaruhi satu sama lain. Jumlah peserta KB aktif di Kab. Garut dipengaruhi oleh jumlah peserta KB aktif di Kab. Garut pada satu periode sebelumnya dan oleh jumlah peserta KB aktif di Kab. Bandung satu periode sebelumnya. Dengan demikian, Jumlah peserta KB aktif di Kab. Bandung dipengaruhi oleh jumlah peserta KB aktif di Kab. Bandung pada satu periode sebelumnya dan oleh jumlah peserta KB aktif di Kab. Garut satu periode sebelumnya. 
Nilai R2 dan Adjusted R2 tiap persamaan parsial model VARI (1,1) cenderung kecil, yaitu 13,35\% dan 11,99\% untuk Kab. Garut, serta 4,5\% dan 3\% untuk Kab. Bandung. Hal ini menunjukkan bahwa keragaman model masing-masing persamaan parsial belum dapat dijelaskan oleh variabel jumlah peserta KB aktif di Kab. Garut dan Kab. Bandung secara simultan, tetapi masih terdapat variabel lain di luar model yang lebih berpengaruh pada periode penelitian tersebut.

\subsection{Diagnostik Model}

Diagnostik model perlu dilakukan untuk mengetahui kelayakan model. Diagnostik model yang dilakukan adalah pemeriksaan asumsi residual. Model dikatakan layak jika antar residual saling bebas (white noise), ragam residual mengikuti sebaran normal dan tidak terdapat efek $\mathrm{ARCH}$ (residual konstan).

\subsubsection{Uji Multivariate White Noise Residual}

Dengan taraf signifikansi $10 \%$, hasil pengujian menggunakan Portmanteau Test menunjukkan bahwa $H_{0}$ terima $(p-$ value $=0.6321>0.10)$. Oleh karena itu, dapat disimpulkan bahwa model $\operatorname{VARI}(1,1)$ telah memenuhi syarat multivariate white noise.

\subsubsection{Uji Residual Berdistribusi Multivariate Normal}

Dengan taraf signifikansi 10\%, hasil pengujian menggunakan Multivariate Jarque-Berra

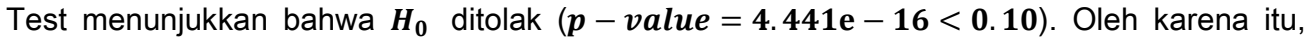
dapat disimpulkan bahwa residual model $\operatorname{VARI}(1,1)$ tidak berdistribusi multivariate normal, artinya tidak memenuhi syarat multivariate normal.

\subsubsection{Uji Heteroskedastisitas Residual}

Dengan taraf signifikansi 10\%, hasil pengujian menggunakan Lagrange Multiplier Test menunjukkan bahwa $\boldsymbol{H}_{\mathbf{0}}$ diterima $(\boldsymbol{p}-$ value $=\mathbf{0 . 9 9 2}>\mathbf{0 . 1 0})$. Oleh karena itu, dapat disimpulkan bahwa residual model $\operatorname{VARI}(1,1)$ bersifat homogen, artinya memenuhi syarat homogenitas residual.

\section{KESIMPULAN}

Pemodelan jumlah peserta KB aktif di Kab. Garut dan Kab. Bandung mengunakan model VARI $(1,1)$ diperoleh hasil sebagai berikut :

Garut $_{t}=849.038-0.380$ Garut $_{t-1}+0.032$ Bandung $_{t-1}$ Bandung $_{t}=1646.217-0.079$ Bandung $_{t-1}-0.206$ Garut $_{t-1}$

Dua persamaan diatas menunjukkan bahwa variabel yang diamati, yaitu jumlah peserta KB aktif di Kab. Garut dan Kab. Bandung, saling mempengaruhi satu sama lain. Jumlah peserta KB aktif di Kab. Garut dipengaruhi oleh jumlah peserta KB aktif di Kab. Garut pada satu periode sebelumnya dan oleh jumlah peserta KB aktif di Kab. Bandung satu periode sebelumnya. Dengan demikian, Jumlah 
peserta KB aktif di Kab. Bandung dipengaruhi oleh jumlah peserta KB aktif di Kab. Bandung pada satu periode sebelumnya dan oleh jumlah peserta KB aktif di Kab. Garut satu periode sebelumnya.

Hasil diagnostik model terhadap residual menunjukkan bahwa model VARI $(1,1)$ telah memenuhi homogenitas residual dan multivariate white noise residual, namun belum memenuhi asumsi residua/berdistribusi multivariate normal. Selanjutnya, nilai $\mathrm{R}^{2}$ dan Adjusted $\mathrm{R}^{2}$ tiap persamaan parsial model $\operatorname{VARI}(1,1)$ cenderung kecil. Hal ini menunjukkan bahwa keragaman model masingmasing persamaan parsial belum dapat dijelaskan oleh variabel jumlah peserta KB aktif di Kab. Garut dan Kab. Bandung secara simultan, tetapi masih terdapat variabel lain di luar model yang lebih berpengaruh pada periode penelitian tersebut.

\section{DAFTAR PUSTAKA}

[1] BKKBN. 2015. Panduan Tata Cara Pengelolaan Data Rutin Pelayanan KB Program Kependudukan, Keluarga Berencana dan Pembangunan Keluarga. Jakarta : Direktorat Pelaporan dan Statistik, BKKBN.

[2] BPS. 2018. Provinsi Jawa Barat Dalam Angka 2018. Bandung : Badan Pusat Statistik (BPS) Provinsi Jawa Barat.

[3] Enders, W. (1995) Applied Econometric Time Series. John Wiley \& Son, Inc. USA.

[4] Mulyana. 2004. Buku Ajar Analisis Data Deret Waktu. Jatinangor : Jurusan Statistika, FMIPA, Universitas Padjadjaran (UNPAD).

[5] Mulyaningsih, T., Ruchjana, B. N., \& Soemartini. 2013. Pendekatan Model Time Series untuk Pemodelan Inflasi Beberapa Kota di Jawa Tengah. http://pustaka.unpad.ac.id/wp-content/uploads/2015/01/MakalahSemnas_TriMulyaningsih_140720131.p.

[6] Wei, W.W.S. 2006. Time Series Analysis Univariat and Multivariate Methods Second Edition. Canada : Addison-Wesley Publishing Co.

[7] aplikasi.bkkbn.go.id/sr, diakses 14 Maret 2019.

[8] http://disperindag.jabarprov.go.id/assets/img/peta_jabar.png, diakses 18 Maret 2019. 